\title{
Kurumsal Tasarımın Kurumsal İmaj ve Kurumsal İtibar Oluşumu Üzerine Etkisinin Hizmet Sektöründe İncelenmesi (Examining Corporate Designs' Effect on Forming Corporate Image and Corporate Reputation in the Services Industry)
}

\author{
Fikret CANITEZ ${ }^{D_{a}}$ Ayşe AKYOL ${ }^{\left(D_{b}\right.}$ \\ a fikretcanitez@gmail.com \\ b İstanbul Arel Üniversitesi, İstanbul, Türkiye. ayseakyol@arel.edu.tr
}

\begin{tabular}{ll}
\hline MAKALE BİLGİSİ & ÖZET \\
\hline $\begin{array}{l}\text { Anahtar Kelimeler: } \\
\text { Kurumsal Tasarım }\end{array}$ & $\begin{array}{l}\text { Amaç - Benzer mal ve hizmet sunulan bir ortamda sürdürülebilir büyüme ve başarı elde etmek, } \\
\text { ancak müşterinin nezdinde rakiplerden farklı algılanma ile mümkündür. Bir kurumun tasarımı, } \\
\text { Kurumsal İtibar }\end{array}$ \\
$\begin{array}{l}\text { imajı ve itibarı bu farklılaşmayı sağlayan ana etkenlerin başında gelmektedir. Özellikle fiyat, kalite, } \\
\text { fayda, satıs sonrası servis, garanti gibi hususlar birbirine yakın olduğunda kurum itibarının } \\
\text { tüketici tercihine etkisi büyük ölçüde olmaktadır. Çalı̧mamızda kurumsal tasarımın kurumsal }\end{array}$ \\
$\begin{array}{l}\text { Gönderme Tarihi 11 Aralık 2018 } \\
\text { Revizyon Tarihi 21 Nisan 2019 }\end{array}$ & $\begin{array}{l}\text { itibar oluşumuna olan doğrudan etkisi ile kurumsal tasarımın kurumsal imaj üzerinden kurumsal } \\
\text { itibar oluşumuna olan dolaylı etkisi incelenmiştir. }\end{array}$
\end{tabular}
Kabul Tarihi 5 Temmuz 2019

Makale Kategorisi: Araştırma Makalesi

Yöntem - Çalışmamızda öncelikle literatür taraması yapılarak kavramsal çerçeve oluşturulmuş, yapı geçerliliği kapsamında pilot uygulama ve daha sonra sosyal ağlar ve elektronik posta aracılığıyla gönderilen anketi cevaplayan 804 kişi örneklem olarak alınarak saha çalışması yapılmıştır. Daha sonra veriler SPSS 22.0 ve AMOS 22.0 yazılımlarıyla çözümlenmiş, elde edilen verilere güvenilirlik analizi, KMO testi, açklayıcı faktör analizi, korelasyon analizi, doğrulayıcı faktör analizi yapılmış, hipotezler yapısal eşitlik modeli ile test edilmiş ve bunun sonucunda bazı hipotezlerin tamamen, bazılarının ise kısmen kabul edildiği gözlemlenmiştir.

Bulgular - Çalışmamız sonucunda kurumsal tasarım ile kurumsal itibar oluşumu arasında orta düzeyde, kurumsal imaj ile kurumsal itibar oluşumu arasında güçlü, kurumsal tasarım ile kurumsal imaj arasında yine güçlü düzeyde bir ilişki olduğu görülmüştür.

Tartışma - Araştırmamızın en önemli çıktısı kurumsal tasarımın kurumsal itibar oluşumunu etkilediğinin istatistiksel olarak anlamlı çıkmasıdır. Bir diğer sonuç kurumsal tasarımın kurumsal imajı etkilediğinin ortaya çıkarılmasıdır. Araştırmamızın bir diğer önemli sonucu da kurumsal imajın kurumsal itibar oluşumunu etkilediğinin istatistiksel olarak doğrulanmış olmasıdır.

\begin{tabular}{ll}
\hline ARTICLE INFO & ABSTRACT \\
\hline $\begin{array}{l}\text { Keywords: } \\
\text { Corporate Design } \\
\text { Corporate Image }\end{array}$ & $\begin{array}{l}\text { Purpose - To achieve sustainable growth and success in an environment where similar products } \\
\text { and services are offered are only possible offering a different perception of the same product from } \\
\text { the competitors. The design, image and reputation of a corporation are among the main factors } \\
\text { which provide this difference. Especially when prices, quality, benefits, after sales services, } \\
\text { guarantees and such particularities are similar to each other, the corporate's reputation has a large } \\
\text { impact on consumers' choices. In our study, the direct effect of corporate design on the formation } \\
\text { Received 11 December 2018 } \\
\text { of corporate reputation and the indirect effect of corporate design on corporate reputation } \\
\text { Accepted 5 July 2019 }\end{array} \quad \begin{array}{l}\text { formation are examined. } \\
\text { Design/methodology/approach - We have first formed a conceptual framework resulting from an } \\
\text { extensive literature search. A pilot scheme was conducted within the scope of construct validity } \\
\text { and than afield study was conducted involving } 804 \text { participants who answered the questionnaires } \\
\text { sent via social networks and e-mail. The data gathered were analyzed with SPSS 22.0 and AMOS } \\
\text { 22.0 software. Reliability analysis, KMO test, explanatory factor analysis, correlation analysis, } \\
\text { confirmatory factor analysis were applied and hypotheses were tested with astructural equation } \\
\text { model. As a result some hypotheses are fully accepted when some partially accepted. } \\
\text { Findings - As a result of our study, we have come to the conclusion that while there is a medium } \\
\text { level relationship between corporate design and corporate reputation formation, there is a strong } \\
\text { relationship between corporate image, design and corporate reputation formation. } \\
\text { Discussion - The most important output of our research is that the corporate design is statistically } \\
\text { significant and that corparate design affects the formation of corporate reputation. Furthermore, } \\
\text { we came to the conclusion that corporate design affects corporate image and more importantly that } \\
\text { the corporate image affecting the formation of the corporate reputation is statistically verified. }\end{array}$ \\
\end{tabular}




\section{GİRIŞ}

Tüketici ihtiyaç ve beklentilerinin her geçen gün farklılaştığı, piyasada benzer mal ve hizmet üreten firma sayısının giderek arttığı, küreselleşmenin yoğun şekilde devam ettiği, teknolojinin hızlı geliştiği ve hemen her türlü bilgiye erişimin çok kolay olduğu günümüz dünyasında rekabet de tüm hızıyla devam etmektedir. İşletmelerin böylesine sert ve zorlu bir ortamda varlıklarını sürdürebilmeleri, tüketicilerin gözünde farklı bir konuma sahip olmaları, tüketiciler nezdinde rakiplerinden farklılaşmalarıla mümkündür.

Yapılan araştırmalar, sürdürülebilir büyüme ve rekabet üstünlügünün, tüketiciler için katma değer yaratan mal ve hizmet üretiminin yanı sıra, bu mal ve hizmeti üreten firmanın itibarına, imajına ve kurumsal tasarımına da bağlı olduğunu göstermektedir.

Bu bağlamda ilk öne çıkan unsurlardan biri kurumsal tasarımdır. Kurumsal tasarım, kurum kimliğini görsel bir şekilde ifade etme yeteneğine sahiptir. Bunun için yapılması gereken kurumun gücünü ve yönünü hızlı ve etkili bir şekilde iletebilen bir kimlik ve görsel imaj yaratmaktadır. Çünkü bir kurumun yaptığı işin ya da kısaca bir markanın en etkili bir şekilde algılanmasında, akıllarda yer edinmesinde ve hedeflenen çevreler üzerinde itibar elde etmesinde görsel kimliğin çok büyük katkısı bulunmaktadır. Kurumsal görsel kimlik, iç ve dış müşterilerin firma hakkındaki düşüncelerini etkileyip kurumsal itibarın oluşmasına yardımcı olmaktadır. Firmaların logoları, sloganları ve reklamları müşteriler üzerinde firmaya ait güven, sadakat ve itibar oluşturmaktadır. Kurum kimliği, kurumların ne durumda olduğunu gösteren kılavuz niteliğinde bir araçtır. Uzun vadede kuruma rekabet avantajı elde etmesini sağlayabilmektedir. Küreselleşen dünyada başarıya erişmenin tek yolu başkalarından farklı olabilmektir ve bu da ancak kurum kimliği ile sağlanabilmektedir. Kurumsal itibarı yüksek olan kurumların kurum kimlikleri, onları en iyi şekilde yansitmaktadır (Kara, 2014).

Kurumsal itibar, firmanın aslında iyi ya da kötü olduğu konusunda hedef pazardaki müşterilerin değerlendirmesini gösteren manevi değer olarak tanınmaktadır (Bozkurt, 2005).

Erdem (2015),kurumsal kimlik ve unsurlarını açıklamış (kurumsal felsefe, imaj, iletişim, kültür, davranış, tasarım) ve incelemiştir.

Savaşkan (2017), kurumsal kimliğin ilişkili olduğu alanlar olarak kurum kültürü, iklimi, imajı, itibarı ve iletişimini açıklamış; kurumsal kimliğin bileşenleri olarak kurumsal felsefe, davranış ve tasarımını incelemiştir.

Salman ve Eroğlu (2017) kurumsal Facebook sayfalarında kurum kimliği unsurlarının ne düzeyde yansıtıldığını belirlemeyi amaçlayarak, kurum kimliğini oluşturan kurum felsefesi, kurumsal tasarım, kurumsal iletişim ve kurumsal davranış boyutlarını incelemiştir.

Koçer (2017), üniversitelerin kurumsal web sitelerini, kurum kimliği unsurları açısından (kurum tasarım unsurları ve kurum kültürü, kurum davranışı, kurumsal iletişim, stratejileri, kurumsal yapıları ve endüstri kimlikleri) incelemiştir.

Topçu (2017), kurumsal kimlik oluşturmada etkili bir logonun marka üzerindeki etkisini incelemiş, "Juventus" kulübünün logo değişim sürecini de değerlendirmiştir.

Bayar (2018), kurumsal itibar ve ilişkili olduğu diğer kavramları (kurumsal iletişim, kurum kültürü, kurum kimliği, kurum imajı, kurum markası) açıklamış; kurumsal itibar algısının örgütsel vatandaşlık davranışına etkisini incelemiştir.

Dumlu ve Kaygısız (2018) çalışmasında, futbol takımlarına ait internet sitelerinin kurumsal itibar bağlamında itibar kriterlerine uygunluğunu değerlendirmişlerdir.

Öztürk ve Şardağı (2018), Türkiye'de faaliyet gösteren vakıf ve derneklerin resmi Facebook hesaplarını, kurumsal kimlik unsurları açısından (kurumsal davranış, iletişim, tasarım ve felsefe) incelenmiştir. Kurumsal kimliğin etkileşim alanları olan kurum kültürü ve imaj unsurları, kurumsal kimliğin bütünsel bir perspektiften ortaya çıkarılması için çalışmaya dâhil edilmiştir.

Kiessling ve Spannagli, (1996), Birkigt vd., (1993:19), Melewar ve Jenkins, (2002), Melewar ve Karaosmanoğlu, (2006) ve Uslu, (2006:47)'nin Kurumsal kimliğin unsurları çalışmaları incelendiğinde genel olarak, kurumsal kimliğin; kurumsal tasarım, kurum felsefesi, kurumsal iletişim ve kurumsal davranış olmak üzere dört unsuru olduğu görülmektedir. Bu çalışmada kurumsal tasarım unsuru ele alınacaktır. 
Yukarıdaki bilgiler ışığında bu çalışmada, kurumsal tasarımın kurumsal itibar oluşumuna olan doğrudan etkisi ile kurumsal tasarımın kurumsal imaj üzerinden kurumsal itibar oluşumuna olan dolaylı etkisi incelenmiştir. Çalışma sonuçlarında ulaşılan bulgularla, hem firmaların üst düzey yöneticilerine, hem de pazarlama ve marka yöneticilerinin pazarlama stratejilerini geliştirmelerine yardımcı olacağı değerlendirilen tespitler yapılması amaçlanmıştır.

\section{KURUMSAL TASARIM}

Kurumsal tasarım, kurum kimliği çerçevesinde bir firmanın tasarım stratejisidir. Kurumsal tasarım bir kuruluşun görsel tüm iletişiminin bütünlüğünü sağlamak için yaratıcılık çerçevesi oluşturur. Bir başka deyişle "kurum tasarımı" kavramı, bir firmanın görünümünün kurum kimliği amacına uygun olarak birbiri ile uyumlu olan görülebilen tüm unsurların hedeflenmiş bir şekilde oluşturulmasını kapsar (Okay, 2012).

Kurumsal tasarım, bir kurumun kendisini görsel olarak ifade etmesini sağladığı ve görsel kimliğini oluşturduğu gibi, kurum içinde kimin hangi yetkileri alacağını, kimin neye karar vereceğini belirleyen temelin oluşturulmasıdır Görsel kimlik kurum kimliğini ve kurum kültürünü ifade ederek, kurumun var olan özelliklerini net ve algılanır bir biçimde yansıtmalı, kurumun çevre ile iletişimini sağlamalıdır (Usta, 2012:78).

Balmer (1995:6), kurumsal kimliğin görsel bileşenlerini anlatmak için "görsel özdeşleştirme", Bosch vd., (2005:18) ise isim, sembol, logo, yazı karakteri, renk, slogan ve diğer grafik elemanları temsil etmek için "kurumsal görsel kimlik" terimini kullanmıştır. Dowling (1994:8) davranış ve iletişim bileşenlerini göz ardı ederek "kurumsal kimlik" kavramını kurumun görsel çehresine eşitlemiştir. Melewar ve Karaosmanoğlu (2006:852) kurumsal tasarım ve görsel kimlik terimlerini aynı anlamda kullanmıştır. Bartholme ve Melewar (2011:55), "görsel özdeşleştirme", "kurumsal görsel kimlik", "kurumsal tasarım", "sembolizm" ve hatta "kurumsal kimlik" kavramlarının literatürde kurumun görsel işaretlerini temsil etmek için kullanıldığını ortaya koymuştur.

Kurumsal tasarım bir kurumun faaliyetleri, mal ve hizmetlerinin kuruluş kimliği hedeflerine uygun şekilde tasarlanmasıdır. Bu kapsamda; kurum renkleri, kurum logosu, kırtasiye malzemeleri, antetli kağıtlar, kartvizitler, reklamlar, yazı karakteri, şirket mühürleri, mağazalar, fabrikalar, üniformalar, ürünler, ambalajlar, ulaşım araçları, tabelalar, posterler, reklam tabloları ve paket malzemeleri kurumun kurumsal kimliğini oluşturacak şekilde uyum içinde tasarlanmalıdır.

Kurumsal tasarıma ait üç unsur bulunmaktadır. Bunlar ürün tasarımı, iletişim tasarımı ve çevre tasarımıdır (Okay, 2012);

2.1 Ürün Tasarımı: Ürün; değiş tokuş edebilen veya kullanabilen somut veya soyut niteliklerin bir karışımıdır. Bir ürün bir fikir, bir fiziksel varlık (bir mal) veya bir hizmet veya üçünün herhangi bir kombinasyonu olabilir. Bireysel ve örgütsel amaçların gerçekleştirilmesinde değişim amacıyla kullanılır. (American Marketing Association-AMA 2018)

Ürün tasarımı; pazarlamacılar, araştırma ve geliştirmeciler, mühendisler, finans uzmanları gibi birçok kişinin birlikte çalışmasını gerektiren; fikir oluşturma, konsept yazma, ürününün özelliklerini, kendine özgü karakteristiklerini, ürün kalitesini belirleme, üretim maliyetini hesaplama, analiz ve üretim gibi birçok faaliyeti içeren heyecan verici bir süreçtir.

2.2 İletişim Tasarımı: İletişim tasarımı bir kurumun kendisini tanımlayabildiği ve anlatabildiği, iletişim araçlarının tamamıdır. Bunlar kurumun logosundan, yazılı, işitsel ve görsel basına vermiş olduğu reklamlara kadar uzanabilmektedir (Kaya, 2006:30). İletişim tasarımı aracılığıyla kurumun kendisine sağlayacağı başlıca avantaj, hedef grubuyla iletişiminde kolaylıkla yeniden tanınabilmesi ve daha sonradan bu hatırlanma ve izlenimle bu grup tarafından tercih edilmesidir. Bir kurum, iletişim tasarımındaki tüm alanları ile birlikte bir uyum içerisinde olmalıdır. Eğer kurumun logosunda kullandığı renkler ayrı, kurum sembolünün renkleri ayrı ve çalışanların görünümü farklıysa, bu farklılık o kuruluşun ortak tasarımının oluşturulmasını engeller.

İletişim tasarımı yalnızca dar anlamda pazarlama karması içerisindeki iletişimin dar alanlarını kapsamamaktadır. Aynı zamanda tüm dahili ve harici iletişim süreçlerinin oluşturulmasını ve organizasyonunu da kapsamaktadır. Bu noktada da zaman zaman, kurum kimliğinin unsurlarından olan kurumsal iletişim ile bir kesişme meydana gelmektedir. İletişim tasarımı içerisinde; kurum rengi, kurum 
işareti (kurum logosu ve sembolü), yazı karakteri ve yazı türü, kartvizit ve diğer tüm basılı malzemeler yer almaktadır (Okay, 2000:127).

2.3 Çeore Tasarımı: Kurum mimarisi, kurumun tanınabilirliği, akılda kalıcılığı ve paydaşların edindikleri izlenimler açısından önemlidir. Kurumsal kimliği yansıtan kurum mimarisi, dış mimari tasarımın yanında, iç mimari tasarım ve çalışma ortamı tasarımını da kapsamaktadır. Vitrin-dış cephe ve mağaza tasarımı da kurumsal kimliğin ifadesinde önemli bir yer tutmaktadır.

\section{KURUMSAL IMAJ}

Bir kurumun kimliğini oluşturan kurum felsefesi, kurumsal tasarım, kurumsal iletişim ve kurumsal davranış gibi kurum kimliği öğeleri tarafından ortaya konan fiziksel ve duygusal görüntüsünün, paydaşlar tarafından algılanış ve değerlendirilişi olarak tanımlanan kurumsal imaj, kurum hakkında sosyal çevresinin sahip olduğu izlenimdir (Turhanoğulları, 2010). Yani kurumun hedef kitlesinin kurum hakkındaki duygusal ve akılc1 düşünce ve algılamalarının tümüdür (Önal, 2000:47).

Kurumsal imaj, bir firma hakkında toplumun, tüketicilerin, mal ya da hizmetlerini ulaştırdığı müşterilerinin, rakiplerinin, birlikte iş yaptığ diğer kuruluşların ve kitle iletişim araçlarının edinmiş oldukları izlenimlerdir (Gülsoy, 1998:196). Regenthal'e göre (1992) kurumsal imaj, kurum kimliği etkilerinin personel, hedef kitleleri (paydaşlar, müşteriler) ve kamuoyu üzerindeki sonucudur.

Kurumsal imaj algılanan kaliteyi etkiler ve müşteri memnuniyeti üzerinde ciddi bir etkileme gücü oluşturur. Karmaşık ve çok sık satın alınmayan mal ve hizmetler için müşteri bağlllığı yaratmada önemi daha fazladır. İyi planlanmış bir kurumsal imaj süreci, kuruma yüksek derecede fark edilirlik ve sevilen bir itibar kazandırır. İyi bir imaj ile itibar arasındaki etkileşim ise müşteri bağlılığının gelişmesini sağlar. Özellikle sınırların hızla ortadan kalktığı küresel iş dünyasında, rekabetin acımasız bir hal almış olması nedeniyle kurumsal imaj ve ilişkili pazarlama süreçleri, çok iyi yönetilmesi gereken kavramlar olarak tepe yönetimlerin görevleri arasında yer almaktadırlar (Erdoğan ve Gönüllüoğlu, 2006:49).

\section{KURUMSAL İTIBBAR}

Kurumsal itibar, kurumların geçmişteki hareketleri ve değişik paydaşlar üzerinde değer yaratan etkiler bırakma yeteneği sonuçlarının kolektif betimlemesidir. $\mathrm{Bu}$, hem iç hem de dış paydaşların göreceli durumlarını ölçmekte; hem rekabete dayalı olmakta hem de kurumsal çevreleri içermektedir (Fombrun ve Riel, 1997). Kurumsal itibar; genel olarak paydaşların 'kurumun ne olduğu', 'kurumun sorumluluklarını nasıl yerine getirdiği', 'paydaşların beklentilerinin nasıl karşıladığı' ve 'kurumun sosyal-politik çevreye uyum sağlamaktaki bütün performansına' ilişkin değerlendirmelerinin uzun dönemli kombinasyonudur (Anca ve Roderick, 2007: 234).

İtibar yalnızca kurumdan gönderilen bilgi işaretleri ya da diğer bilgi araçları ile şekillenmemektedir. Kurumların davranışları hakkında paydaşların algılamaları ve yorumları da itibarı oluşturmaktadır. Bu algılamalar ve yorumlar, kurum tarafından gönderilen bilgi işaretlerinin paydaşlar tarafından nasıl anlaşıldığını göstermektedir. Sabit ve dinamik koşullar altında bazı paydaş gruplarının karmaşık etkileşimleri, bilgi işaretlerinin tam ve doğru olarak anlaşılamamasına neden olabilmektedir (Dentchev ve Aimé, 2006).

Fombrun ve Van Riel (2004) itibar oluşumunu sağlayan faktörleri: görünebilirlik, ayırt edilebilirlik, aslına uygunluk, şeffaflık ve tutarlılık olarak sıralamıştır.

4.1 Görünebilirlik: Görünebilirlik, müşterilerin zihninde oluşan marka ününün bir ölçeğidir (Bosch vd., 2005:109). Diğer bir tanımda ise görünebilirlik, firmanın tüm basın-yayın organlarında ve kamuoyu iletişim ortamlarında göz önünde bulunması olarak tanımlanabilir. Fombrun ve Van Riel (2004)'in RQ (Reputation Quotient) projesinden elde ettikleri bilgilere göre kamuoyu bir firmaya ne kadar aşina ise o firmayı o kadar iyi değerlendirir. Her ne kadar itibar ve aşinalık güçlü bir şekilde ilişkili olsa da, itibar sadece görünür olmak veya kamuoyu tarafından iyi tanınmaktan daha fazlasıdır. Yüksek itibarlı firmalar sadece bilindik değil, aynı zamanda görünürdür.

4.2 Ayırt Edilebilirlik: Ayırt edilebilirlik bir firmanın müşterileri ve diğer paydaşlarının gözündeki eşsiz konumudur (Bosch vd., 2005:110). Kurumlar benzerlerinden ayırt edilebilir oldukları sürece rakipleri arasında 


\section{F. Canitez - A. Akyol 11/3 (2019) 1294-1312}

farklı bir konum edinirler ve bu ayırt edilebilir özellikleri sayesinde yüksek itibar kazanırlar. Bu nedenle itibar kazanmak isteyen firmalar diğerlerini taklit etmek yerine diğerlerinden farklı olmaya çalışmalıdır.

4.3 Aslına Uygunluk: Aslına uygunluk, ikna edici bir kimlik oluşturmak için keşif süreci ile başlar ve sonrasında dahili ifade ve harici ifade süreçleri ile devam eder. Aslına uygun olmak demek, söylenenler ve yapılanlar arasındaki farkın azaltılması anlamına gelir. Firmaların bunu başarması çok kolay değildir. Bir firmanın aslına uygunluk algısı, itibar yönetimi ile doğrudan ilişkilidir. Firmalar paydaşlarla olan tüm etkileşimlerinde mutlak dürüstlük göstermek zorundadır. Aksi halde bir paydaşın firmayı kötülemesi, anında diğer paydaşlara iletilmesi ve firma için hissettikleri destek derecesinin azalması ile sonuçlanacaktır (Fombrun ve Van Riel, 2004:162).

4.4 Şeffaflı: Firmanın finansal gücü, ürün yenilikleri, faydaları, firma politikası ve amaçları gibi bir çok konuda ortakların devamlı ve kapsamlı bilgilendirilmesine şeffaflık denir (Ülger, 2003:95).

Bir firma ne kadar şeffaf ise paydaşların firmaya olan güveni o derece yüksektir. Şeffaflık güveni arttırmanın yanında firma hakkındaki belirsizlikleri azaltır. Şeffaf bir firma, firmanın mevcut faaliyetleri ve gelecek planları hakkında doğru bir değerlendirme yapılabilmesi için paydaşlarına gerekli bilgilere erişim imkânı verir (Fombrun ve Van Riel, 2004:187).

Firmalar finansal verileri dahil olmak üzere, firma içi ve dışı tüm faaliyetlerinde şeffaf politikalar izleyerek paydaşları ve diğerleri gözünde yüksek itibarlı firma haline gelebilirler.

4.5 Tutarlılık: Kurumlar, felsefelerini ve değerlerini belirlerken paydaşlarına danışmalı ve bu ortak anlayışın ürünleriyle ilgili mesajları topluma açıç̧a iletmelidir. Bu noktada sorun ise, farklı paydaş toplulukların kurumdan bekledikleri ve istediklerinin de farklı olmasıdır. Dolayısıyla hepsini tatmin etmenin zor olduğu günümüz dünyasında tutarlılık ön plana çıkan bir kavramdır (Theaker, 2006:139).

Kurumlar itibar oluşturmak için paydaşlarına karşı birçok açıdan, tutarlı davranışlar ortaya koymak durumundadır. Çıktıların tutarlılı̆̆ıyla ilgili olan bu süreçte, kurumlar iki alanda tutarlılığı sağlamalıdır, topluma verilen mesajlarda ve kurum içindeki kurmuş oldukları iletişimde Kurum, mal ve hizmetler, maddi durum, ulaşılan hedefler, kalite, zamanında yapılan teslimatlar gibi konularda içte ve dişta verdiği sözleri yerine getirmesi gibi konularda tutarlı bir görünüm ortaya koymalıdır (Akahmet, 2006:64).

\subsection{Kurumsal İtibar ile Kurumsal İmaj Arasındaki İlişki}

"Kurumsal imaj" ile "kurumsal itibar" kavramları arasındaki ilişki, farklı yaklaşımlar çerçevesinde ele alınan konulardan birisidir. Kurumsal imajla kurumsal itibarı eşdeğer gören (Odabaşı, 1995:91) bir anlayışın yanında, bu iki kavramı farklı kabul eden bir yaklaşım da mevcuttur (Nguyen ve Leblanc, 2001:230).

Her iki kavramın aynı anlama geldiğini kabul edenler, kurumsal itibar yerine kurumsal imaj kavramını tercih etmektedirler. İkinci yaklaşımı savunanlar ise kurumsal imaj ile kurumsal itibarın farklı kavramlar olarak ele alınması gerektiğini ileri sürmektedir. Ancak, bu yaklaşımı savunanların da homojen bir yapı oluşturdukları söylenemez. Çünkü bu yaklaşımda, kurumsal imaj ile itibarı tamamen birbirinden ayrı olarak görenler şeklinde bir kutuplaşma söz konusudur (Odabaşı ve Oyman, 2002:142-143).

İki kavramı birbirinden tamamen farklı görenlerin en temel argümanı, itibar ve imajın oluşmasında geçen sürenin farklı olmasıdır. Bu görüşü savunanlara göre imaj, kişilerin bir kurum hakkındaki çok uzun dönemli değil, en son inançlarına odaklanmaktadır (Balmer, 1998:971).

Kurumsal imaj zamanınızın koşulları çerçevesinde kısa bir süre içerisinde oluşturulabilir. Kurumsal itibar uzun bir süreç gerektiren, kurumun algılanmasında birikimli olarak gelişen bir unsur olarak kurumsal imajdan farklıdır ve imaj gibi çabucak yaratılamayacağı düşünülmektedir (Odabaşı ve Oyman, 2002:143).

İmaj, kurumun paydaşlarının zihnindeki resim; itibar ise paydaşların kurum hakkındaki değerlendirmeleridir. İmaj daha kısa sürede, itibar ise daha uzun sürede kazanılır. Kurumsal imaj, kurumsal itibara göre daha az sabit olup değişime daha yakındır (Gümüş ve Öksüz, 2009:28).

Ancak Nguyen ve Leblanc (2001:230), bunun tam tersini savunmakta ve kurumsal imajın oluşması için, kurumsal itibarın oluşumuyla kıyaslandığında daha uzun bir zamanın gerekli olduğunu iddia etmektedirler. Ayrıca bu yazarlara göre, kurumsal imajla kurumsal itibarın farklarından biri de, ölçülmelerindeki zorluk düzeyidir. Kurumsal imajın ne derecede olduğunun tespiti, kurumsal itibarın düzeyinin belirlenmesinden zor 
olduğu görüşündedirler. Duncan'a (2002:540) göre, kurumsal imaj ve kurumsal itibar arasındaki farklılık bazen karmaşık bir konudur. Ancak Duncan, imajın yaratılabileceğini, buna karşın itibarın ise kazanılacağı kanaatindedir.

\section{ARAŞTIRMA METODU}

\subsection{Araştırmanın Amacı, Kapsamı ve Türü}

$\mathrm{Bu}$ çalışmada kurumsal tasarımın kurumsal itibar oluşumuna olan doğrudan etkisi ile kurumsal tasarımın kurumsal imaj üzerinden kurumsal itibar oluşumuna olan dolaylı etkisinin incelenmesi amaçlanmıştır.

Araştırmanın türü açıklayıcı araştırmadır. Bu kapsamda internet ortamında yapılan anket yöntemi kullanılmıştır. Çalışmada öncelikle literatür taraması yapılarak kavramsal çerçeve oluşturulmuş, içerik geçerliliği kapsamında uzman görüşüne sunulan ölçek ile daha sonra yapı geçerliliği kapsamında pilot uygulama yapılmıştır.

\subsection{Araştırmanın Modeli}

Konuya yönelik yapılan bilimsel araştırmalar incelenmiş ve amaca uygun olarak Şekil 5.1'de verilen model tasarlanmıştır.

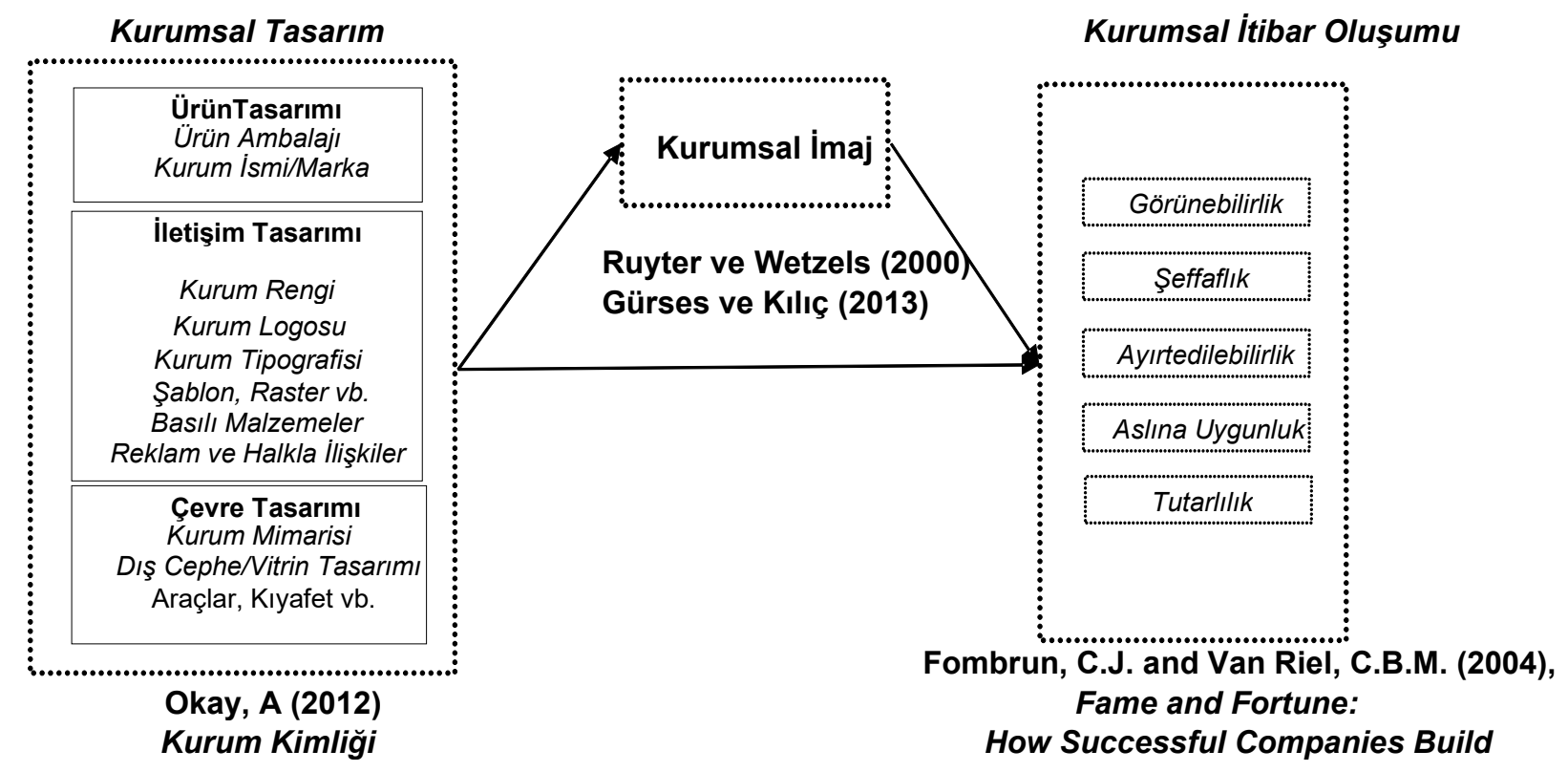

Şekil 5.1. Araştırmanın Modeli

\subsection{Veri Toplama Metodu}

$\mathrm{Bu}$ araştırmada kolayda örnekleme yöntemi ile belirlenmiş 804 kişiye sosyal ağlar ve elektronik posta aracılığıyla anket yapılmıştır.

Bilgiler, kapalı uçlu 57 sorudan oluşan ve likert ölçeğinin kullanıldığı bir anket aracılığıyla toplanmıştır. Anket, demografik veriler, kurumsal tasarım, kurumsal itibar oluşumu ve kurumsal imaj olmak üzere 4 ana bölümden oluşmaktadır. Çalışmada kurumsal tasarım alt unsurları olan iletişim tasarımı, çevre tasarımı ve ürün tasarımı alt başlıkları Okay (2012); kurumsal itibar oluşumu unsurları olan görünebilirlik, şeffaflık, ayırt edilebilirlik, aslına uygunluk ve tutarlılık alt başlıkları Fombrun (2004); kurumsal imaj kavramı Ruyter ve Wetzels (2000) ile Gürses ve Kılıç (2013) çalışmaları baz alınarak oluşturulmuştur. Demografik veriler bölümünde yaş, cinsiyet, eğitim düzeyi, gelir düzeyi ve havayolu kullanımı gibi bilgilerin ölçüldüğü 9 soru bulunmaktadır. Kurumsal tasarım bölümü kendi içinde 3 alt unsura ayrılmakta ve toplam 23 sorudan oluşmaktadır. Alt unsurlar ve soru dağılımları ise sırasıyla: Ürün tasarımı 5 soru, iletişim tasarımı 12 soru ve çevre tasarımı 6 sorudan oluşmaktadır. Kurumsal itibar oluşumu, 5 alt unsurdan ve toplam 22 sorudan oluşmaktadır. Bunlar sırasıyla: Görünebilirlik 4 soru, şeffaflık 5 soru, ayırt edilebilirlik 6 soru, aslına uygunluk 3 soru ve tutarlılık 4 soru şeklindedir. Kurumsal imaj ise 12 sorudan oluşan tek boyutlu bir değişkendir. 
F. Canitez - A. Akyol 11/3 (2019) 1294-1312

Anketin cevapları beşli likert ölçeğine göre toplanmıştır ve bunlar 1=Kesinlikle Katılmıyorum, 2=Katılmıyorum, 3=Ne Katılıyorum-Ne Katılmıyorum, 4=Katılıyorum, 5=Kesinlikle Katılıyorum şeklinde ölçeklendirilmiştir.

\subsection{Araştırmanın Hipotezleri}

\subsubsection{Doğrudan Etkiler:}

Hı: Kurumsal tasarım bileşenlerinin (ürün tasarımı, iletişim tasarımı, çevre tasarımı) kurumsal imaj üzerinde doğrudan etkisi vardır.

H2: Kurumsal tasarım bileşenlerinin (ürün tasarımı, iletişim tasarımı, çevre tasarımı) kurumsal itibar oluşumu bileşenlerinden olan görünebilirlik üzerinde doğrudan etkisi vardır.

H3: Kurumsal tasarım bileşenlerinin (ürün tasarımı, iletişim tasarımı, çevre tasarımı) şeffaflık üzerinde doğrudan etkisi vardır.

H4: Kurumsal tasarım bileşenlerinin (ürün tasarımı, iletişim tasarımı, çevre tasarımı) ayırt edilebilirlik üzerinde doğrudan etkisi vardır.

H5: Kurumsal tasarım bileşenlerinin (ürün tasarımı, iletişim tasarımı, çevre tasarımı) aslına uygunluk üzerinde doğrudan etkisi vardır.

H6: Kurumsal tasarım bileşenlerinin (ürün tasarımı, iletişim tasarımı, çevre tasarımı) tutarlılık üzerinde doğrudan etkisi vardır.

$\mathbf{H}_{7}$ : Kurumsal imajın, kurumsal itibar oluşumu bileşenlerinden olan görünebilirlik üzerinde doğrudan etkisi vardır.

Hs: Kurumsal imajın şeffaflık üzerinde doğrudan etkisi vardır.

H9: Kurumsal imajın ayırt edilebilirlik üzerinde doğrudan etkisi vardır.

H10: Kurumsal imajın aslına uygunluk üzerinde doğrudan etkisi vardır.

H11: Kurumsal imajın tutarlılık üzerinde doğrudan etkisi vardır.

\subsubsection{Dolaylı Etkiler:}

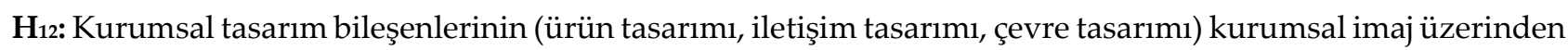
görünebilirliğe dolaylı etkisi vardır.

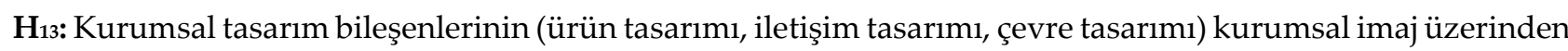
şeffaflığa dolaylı etkisi vardır.

H14: kurumsal tasarım bileşenlerinin (ürün tasarımı, iletişim tasarımı, çevre tasarımı) kurumsal imaj üzerinden ayırt edilebilirliğe dolaylı etkisi vardır.

H15: Kurumsal tasarım bileşenlerinin (ürün tasarımı, iletişim tasarımı, çevre tasarımı) kurumsal imaj üzerinden aslına uygunluğa dolaylı etkisi vardır.

H16: Kurumsal tasarım bileşenlerinin (ürün tasarımı, iletişim tasarımı, çevre tasarımı) kurumsal imaj üzerinden tutarlılığa dolaylı etkisi vardır.

\subsection{Güvenilirlik Analizi}

Çalışmada anketin tüm sorularına uygulanan analiz sonucunda, Cronbach alfa katsayısı 0,969 çıkmıştır. Bu da yapılan anketin güvenilirliğinin yüksek seviyede olduğunu göstermiştir.

Verilerin normallik durumunu test etmek için, grafik yöntemine göre toplanmış olan verilerin Q-Q grafiği oluşturulmuş ve analizde kullanılan verilerin normal dağılıma sahip olduğu görülmüştür. Ayrıca verilerin çarpıklık ve basıklık değerleri incelenmiş ve verilerin normallik varsayımını sağladıkları gözlemlenmiştir. 


\subsection{Açıklayııı Faktör Analizi}

Verilerin normallik durumunu test etmek için, grafik yöntemine göre toplanmış olan verilerin Q-Q grafiği oluşturularak ve verilerin normal dağılım eğrisi üzerinde bir form oluşturup oluşturmadığı incelenmiştir. Q$Q$ grafikleri incelendiğinde, analizde kullanılan verilerin normal dağılıma sahip olduğu görülmektedir.

Q-Q plot çizimlerinin yanı sıra her bir alt unsurun normallik varsayımının incelendiği basıklık, çarpıklık, ortalama ve standart sapma değerleri hesaplanmış ve değişkenlerin tamamının \pm 3 sınırları içinde yer alması nedeniyle verilerin normallik varsayımını sağladıkları görülmüştür.

Bartlett testi ve KMO değeri Tablo 5.1'de verilmiştir.

Tablo 5.1. KMO ve Bartlett Testlerinin Sonuçları

\begin{tabular}{|l|l|l|}
\hline \multicolumn{2}{|c|}{ Kaiser-Meyer-Olkin Örneklem Uyum Değeri } & 0,96 \\
\hline \multirow{3}{*}{ Bartlett Testi } & Yaklaşık Ki-Kare değeri & 26791,833 \\
\cline { 2 - 3 } & sd(serbestlik derecesi) & 1596 \\
\cline { 2 - 3 } & Sig=p (değer) & 0,000 \\
\hline
\end{tabular}

KMO katsayısı $(0,96)$ olarak hesaplanmış ve elde edilen örneklem büyüklügünün faktör analizi uygunluğu için mükemmel olduğu görülmüştür. Ayrıca Bartlett sınaması değerinin 26791,833 olması nedeniyle Bartlett küresellik testinin anlamlı olduğu gözlemlenmiştir. Böylece verilere faktör analizi yapılabileceği görülmüştür.

Açıklayııı faktör Analizi Kurumsal Tasarım (Ürün Tasarımı, İletişim Tasarımı, Çevre Tasarımı) ve Kurumsal İtibar Oluşumu (Görünebilirlik, Şeffaflık, Ayırtedilebilirlik, Aslına Uygunluk, Tutarlılık) ölçekleri için ayrı ayrı uygulanmıştır. Faktör analizi sonucunda uygunluğu bozduğu düşünülen aslına uygunluk alt unsuru soruları çalışmadan çıkartılmıştır. Geriye kalan sorulara tekrar faktör analizi ve faktörlerin daha iyi yorumlanmasına yönelik Varimax döndürülmesi uygulanmıştır. Açıklayıcı faktör analizi sonucunda elde edilen tüm bulgular Tablo 5.2' de verilmiştir.

Tablo 5.2. Cronbach Alfa Katsayıları, Özdeğer, Faktör Yükleri, Açılanan Varyans, Birikimli Varyans ve Döndürme ile Açıklanan Varyans Yüzdeleri

\begin{tabular}{|l|c|c|c|c|c|c|}
\hline \multicolumn{1}{|c|}{ İfadeler } & $\begin{array}{c}\text { Cronbach } \\
\text { Alfa }\end{array}$ & Özdeğer & $\begin{array}{c}\text { Faktör } \\
\text { Yükleri }\end{array}$ & $\begin{array}{c}\text { Açıklanan } \\
\text { Varyans } \\
\text { (\%) }\end{array}$ & $\begin{array}{c}\text { Birikimli } \\
\text { Varyans } \\
\text { (\%) }\end{array}$ & $\begin{array}{c}\text { Värimax } \\
\text { Döndürmesi } \\
\text { ile } \\
\text { Açıklanan } \\
\text { Varyans(\%) }\end{array}$ \\
\hline Ürün Tasarımı (UT) & $\mathbf{0 , 7 5}$ & 1,449 & & 2,734 & 57,307 & 4,435 \\
\hline $\begin{array}{l}\text { THY uluslar arası tanınır bir } \\
\text { markadır. }\end{array}$ & & & 0,776 & & & \\
\hline $\begin{array}{l}\text { THY markası, sağladığı } \\
\text { faydalar ve ortaya koyduğu } \\
\text { kalite hakkında izlenim } \\
\text { uyandırır. }\end{array}$ & & & 0,763 & & & \\
\hline $\begin{array}{l}\text { THY'nin adı kalite çağrışımı } \\
\text { yapmaktadır. }\end{array}$ & & & 0,454 & & & \\
\hline THY'nin adını beğeniyorum. & & 6,575 & & 12,404 & 48,286 & 21,838 \\
\hline İletişim Tasarımı (İT) & $\mathbf{0 , 8 6}$ & & 0,520 & & & \\
\hline THY'nin logosu bilindiktir. & & & 0,512 & & & \\
\hline $\begin{array}{l}\text { THY logosunun, firmanın } \\
\text { amacını ortaya koyduğunu } \\
\text { düşünüyorum. }\end{array}$ & & & & & & \\
\hline
\end{tabular}


F. Canıtez - A. Akyol 11/3 (2019) 1294-1312

\begin{tabular}{|c|c|c|c|c|c|c|}
\hline İfadeler & $\begin{array}{l}\text { Cronbach } \\
\text { Alfa }\end{array}$ & Özdeğer & $\begin{array}{l}\text { Faktör } \\
\text { Yükleri }\end{array}$ & $\begin{array}{l}\text { Açıllanan } \\
\text { Varyans } \\
(\%)\end{array}$ & $\begin{array}{l}\text { Birikimli } \\
\text { Varyans } \\
(\%)\end{array}$ & $\begin{array}{c}\text { Varimax } \\
\text { Döndürmesi } \\
\text { ile } \\
\text { Açılanan } \\
\text { Varyans(\%) }\end{array}$ \\
\hline $\begin{array}{l}\text { THY'nin logo tasarımı } \\
\text { ayırtedilebilirdir. }\end{array}$ & & & 0,741 & & & \\
\hline $\begin{array}{l}\text { THY'nin logosunu } \\
\text { beğeniyorum. }\end{array}$ & & & 0,601 & & & \\
\hline $\begin{array}{l}\text { THY'nin yazı karakterini çekici } \\
\text { buluyorum. }\end{array}$ & & & 0,465 & & & \\
\hline $\begin{array}{l}\text { THY'nin yazı karakteri } \\
\text { ilginçtir. }\end{array}$ & & & 0,531 & & & \\
\hline $\begin{array}{l}\text { THY'nin yazı karakteri ilk } \\
\text { bakışta okunabilirdir. }\end{array}$ & & & 0,667 & & & \\
\hline $\begin{array}{l}\text { THY'nin yazı karakteri, logo } \\
\text { mümkün olmadığında bana } \\
\text { hitap edebilmektedir. }\end{array}$ & & & 0,650 & & & \\
\hline THY'nin logo rengi anlamlıdır. & & & 0,657 & & & \\
\hline $\begin{array}{l}\text { THY logosunun rengi } \\
\text { tanınabilirdir. }\end{array}$ & & & 0,632 & & & \\
\hline $\begin{array}{l}\text { THY'nin logosunun rengi } \\
\text { eşsizdir. }\end{array}$ & & & 0,650 & & & \\
\hline $\begin{array}{l}\text { THY'nin logo rengini } \\
\text { beğeniyorum. }\end{array}$ & & & 0,471 & & & \\
\hline Çevre Tasarımı (CT) & 0,74 & 1,147 & & 2,164 & 61,849 & 3,174 \\
\hline $\begin{array}{l}\text { THY uçaklarının dış } \\
\text { görünüşünü güzel buluyorum. }\end{array}$ & & & 0,642 & & & \\
\hline $\begin{array}{l}\text { THY uçaklarının koltukları } \\
\text { ergonomiktir. }\end{array}$ & & & 0,753 & & & \\
\hline $\begin{array}{l}\text { THY uçaklarının iç } \\
\text { dekorasyonu şıktır. }\end{array}$ & & & 0,664 & & & \\
\hline $\begin{array}{l}\text { THY uçaklarının içinde ve } \\
\text { dışında kullanılan renkler } \\
\text { gayet uyumludur. }\end{array}$ & & & 0,629 & & & \\
\hline $\begin{array}{l}\text { THY'nin web sitesinin } \\
\text { tasarımını beğeniyorum. }\end{array}$ & & & 0,590 & & & \\
\hline Görünebilirlik (GR) & 0,57 & 1,034 & & 1,952 & 65,821 & 2,432 \\
\hline $\begin{array}{l}\text { THY markasına ilişkin basında } \\
\text { çıan haberler genelde } \\
\text { olumludur }\end{array}$ & & & 0,658 & & & \\
\hline $\begin{array}{l}\text { THY bilet satış ofisleri birçok } \\
\text { yerde karşıma çıkar. }\end{array}$ & & & 0,609 & & & \\
\hline $\begin{array}{l}\text { THY spor } \\
\text { organizasyonlarındaki } \\
\text { sponsorluklarıyla (Turkish } \\
\text { Airlines Euroleague, Borussia }\end{array}$ & & & 0,735 & & & \\
\hline
\end{tabular}


F. Canitez - A. Akyol 11/3 (2019) 1294-1312

\begin{tabular}{|c|c|c|c|c|c|c|}
\hline İfadeler & $\begin{array}{l}\text { Cronbach } \\
\text { Alfa }\end{array}$ & Özdeğer & $\begin{array}{l}\text { Faktör } \\
\text { Yükleri }\end{array}$ & $\begin{array}{l}\text { Açılklanan } \\
\text { Varyans } \\
(\%)\end{array}$ & $\begin{array}{l}\text { Birikimli } \\
\text { Varyans } \\
(\%)\end{array}$ & $\begin{array}{l}\text { Varimax } \\
\text { Döndürmesi } \\
\quad \text { ile } \\
\text { Açılanan } \\
\text { Varyans(\%) }\end{array}$ \\
\hline \multicolumn{7}{|l|}{$\begin{array}{l}\text { Dorthmund, Manchester Utd., } \\
\text { Barcelona gibi) global anlamda } \\
\text { kendini göstermektedir. }\end{array}$} \\
\hline $\begin{array}{l}\text { THY'nin reklam ve haberlerini } \\
\text { basında ve sosyal medyada } \\
\text { sıkça görürüm. }\end{array}$ & & & 0,610 & & & \\
\hline Şeffaflık (SF) & 0,87 & 3,332 & & 6,287 & 54,573 & 9,101 \\
\hline $\begin{array}{l}\text { THY sağladığı hizmetler } \\
\text { hakkında yeterli bilgi } \\
\text { sunmaktadır (Fiyatlandırma, } \\
\text { uçuş sonrası otel ve araç } \\
\text { kiralama kolaylıkları gibi...). }\end{array}$ & & & 0,585 & & & \\
\hline $\begin{array}{l}\text { THY'nin yönetim şekli ve } \\
\text { stratejisi hakkında bilgi } \\
\text { sahibiyim. }\end{array}$ & & & 0,805 & & & \\
\hline $\begin{array}{l}\text { THY'nin çalışma ortamı } \\
\text { hakkında bilgi sahibiyim. }\end{array}$ & & & 0,843 & & & \\
\hline $\begin{array}{l}\text { THY'nin finansal performansı } \\
\text { hakkında bilgi sahibiyim (Ciro, } \\
\text { Karlılık, vb.). }\end{array}$ & & & 0,762 & & & \\
\hline $\begin{array}{l}\text { THY'nin çevre vb. konulardaki } \\
\text { sosyal sorumluluk } \\
\text { politikalarından haberdarım. }\end{array}$ & & & 0,765 & & & \\
\hline Ayırt Edebilirlik (AE) & 0,77 & 1,760 & & 2,378 & 59,685 & 3,592 \\
\hline $\begin{array}{l}\text { THY'nin sloganı diğer firma } \\
\text { sloganlarına göre etkilidir } \\
\text { (Slogan:Widen Your } \\
\text { World(Dünya daha büyük, } \\
\text { keşfet!)) }\end{array}$ & & & 0,578 & & & \\
\hline $\begin{array}{l}\text { THY, dünya çapında faaliyet } \\
\text { gösteren diğer havayolu } \\
\text { firmalarına göre daha } \\
\text { başarılıdır. }\end{array}$ & & & 0,599 & & & \\
\hline $\begin{array}{l}\text { THY uçakları zamanında } \\
\text { kalkar. }\end{array}$ & & & 0,404 & & & \\
\hline $\begin{array}{l}\text { THY'nin kabin ve ikram } \\
\text { hizmetlerini beğeniyorum. }\end{array}$ & & & 0,652 & & & \\
\hline $\begin{array}{l}\text { THY'nin müşterileriyle ilişkileri } \\
\text { diğer firmalara göre daha } \\
\text { iyidir. }\end{array}$ & & & 0,436 & & & \\
\hline $\begin{array}{l}\text { THY havacılık sektöründe } \\
\text { yenilikçi hizmetleriyle önde } \\
\text { gelen bir firmadır. }\end{array}$ & & & 0,534 & & & \\
\hline Tutarlılık (TU) & 0,74 & 1,071 & & 2,020 & 63,869 & 2,432 \\
\hline
\end{tabular}


F. Canitez - A. Akyol 11/3 (2019) 1294-1312

\begin{tabular}{|c|c|c|c|c|c|c|}
\hline İfadeler & $\begin{array}{l}\text { Cronbach } \\
\text { Alfa }\end{array}$ & Özdeğer & $\begin{array}{l}\text { Faktör } \\
\text { Yükleri }\end{array}$ & $\begin{array}{l}\text { Açıllanan } \\
\text { Varyans } \\
(\%)\end{array}$ & $\begin{array}{l}\text { Birikimli } \\
\text { Varyans } \\
(\%)\end{array}$ & $\begin{array}{l}\text { Varimax } \\
\text { Döndürmesi } \\
\text { ile } \\
\text { Açılanan } \\
\text { Varyans(\%) }\end{array}$ \\
\hline $\begin{array}{l}\text { THY'nin sloganının firma } \\
\text { hedefleriyle örtüştüğ̈ünü } \\
\text { düşünüyorum (Slogan: Widen } \\
\text { Your World(Dünya daha } \\
\text { büyük, keşfet!)). }\end{array}$ & & & 0,412 & & & \\
\hline $\begin{array}{l}\text { THY'nin eylemleri ile } \\
\text { söylemleri örtüşmektedir. }\end{array}$ & & & 0,538 & & & \\
\hline $\begin{array}{l}\text { THY'nin reklam ve } \\
\text { haberlerinin firmanın gelecek }\end{array}$ & & & 0,423 & & & \\
\hline Kurumsal İmaj (İM) & 0,89 & 19,067 & & 35,882 & 35,882 & 18,489 \\
\hline THY markasını beğeniyorum. & & & 0,469 & & & \\
\hline $\begin{array}{l}\text { Diğer tüketicilerin de THY'yi } \\
\text { beğendiğini düşünüyorum. }\end{array}$ & & & 0,469 & & & \\
\hline $\begin{array}{l}\text { Havayolu taşıma firmaları } \\
\text { arasında aklıma gelen ilk firma } \\
\text { THY'dir. }\end{array}$ & & & 0,530 & & & \\
\hline $\begin{array}{l}\text { THY'nin sunduğu hizmet ile } \\
\text { fiyatı dengeli buluyorum. }\end{array}$ & & & 0,432 & & & \\
\hline THY, geniş satış ağına sahiptir & & & 0,496 & & & \\
\hline $\begin{array}{l}\text { THY'yi, müşterilerine karşı } \\
\text { olan 'Garanti ve Teminat' } \\
\text { politikalarında başarılı } \\
\text { buluyorum. }\end{array}$ & & & 0,653 & & & \\
\hline $\begin{array}{l}\text { THY'nin müşteri } \\
\text { hizmetlerinden memnunum. }\end{array}$ & & & 0,662 & & & \\
\hline $\begin{array}{l}\text { THY'nin havacıllk sektörünün } \\
\text { tüm alanlarında uzman } \\
\text { olduğunu düşünüyorum }\end{array}$ & & & 0,649 & & & \\
\hline $\begin{array}{l}\text { THY, gelecek için yüksek } \\
\text { büyüme potansiyeline sahiptir. }\end{array}$ & & & 0,588 & & & \\
\hline $\begin{array}{l}\text { THY, kamu kampanyalarında } \\
\text { aktif rol almaktadır. }\end{array}$ & & & 0,514 & & & \\
\hline $\begin{array}{l}\text { THY, toplum çıkarları ve } \\
\text { huzurunu, firma çıkarları ve } \\
\text { karlılığının üzerinde } \\
\text { tutmaktadır. }\end{array}$ & & & 0,704 & & & \\
\hline $\begin{array}{l}\text { THY, büyük firmalar arasında } \\
\text { etkindir. }\end{array}$ & & & 0,498 & & & \\
\hline
\end{tabular}

Ölçeklerin Cronbach Alfa değerleri: Ürün tasarımında $(0,75)$, iletişim tasarımında $(0,86)$, çevre tasarımında $(0,74)$, görünebilirlikte $(0,57)$, şeffaflıkta $(0,87)$, ayırt edilebilirlikte $(0,77)$, tutarlılıkta $(0,74)$, kurumsal imajda $(0,89)$ olarak bulunmuştur. 
Sosyal Bilimlerde eşik değer faktör yükü 0,30 olarak kabul edilmektedir. Çalışmadan elde edilen sonuçlardan, tüm faktör yüklerinin 0,30' dan büyük olduğu görülmüştür. 8 faktörün (ürün tasarımı, iletişim tasarımı, çevre tasarımı, görünebilirlik, şeffaflık, ayırt edilebilirlik, tutarlılık ve kurumsal imaj) toplam varyansın $\% 65,821^{\prime}$ ini açıladığı söylenebilir. İlk faktör (özdeğeri 19,067 ) varyansın $\% 35,882$ 'sini ve birikimli varyans \%35,882'sini, ikinci faktör (özdeğeri 6,575) varyansın \%12,404'ünü ve birikimli varyans \%48,286'sını, üçüncü faktör (özdeğeri 3,332) varyansın \%6,287'sini ve birikimli varyans \%54,573'ünü, dördüncü faktör (özdeğeri 1,449) varyansın \%2,734'ünü ve birikimli varyans \%57,307'sini, beşinci faktör (özdeğeri 1,260) varyansın \%2,378'ini ve birikimli varyans $\% 59,685$ 'ini, altıncı faktör (özdeğeri 1,147) varyansın \%2,164'ünü ve birikimli varyans $\% 61,849^{\prime}$ unu, yedinci faktör (özdeğeri 1,071) varyansın \%2,02'sini ve birikimli varyans \%63,869'unu, sekizinci faktör (özdeğeri 1,034) varyansın \%1,952'sini ve birikimli varyans \%65,821'ini açıklamaktadır. Elde edilen faktörlerin Varimax döndürmesi sonuçlarından maddelerin toplam 8 faktör altında toplandığı görülmekte olup, faktörler toplam varyansın \%65,821'ini açılamaktadırlar. İlk faktör varyansın \%18,489'unu, ikinci faktör varyansın \%21,838'ini; üçüncü faktör varyansın \%9,101'ini; dördüncü faktör varyansın \%4,435'ini; beşinci faktör varyansın \%3,592'sini; altıncı faktör varyansın \%3,174'ünü; yedinci faktör varyansın \%2,759'unu; sekizinci faktör varyansın \%2,432' sini açılamaktadır.

\subsection{Değı̆şkenler Arasındaki İlişkiler}

Çalışmanın bu aşamasında korelasyon analizi yapılmıştır. Korelasyon analizi anketin üç ana bölümü ve her bir bölümün alt unsurları arasında yapılmıştır. Elde edilen sonuçlar Tablo 5.3'de verilmiştir.

Tablo 5.3. Değişkenler Arası İlişkiler

\begin{tabular}{|c|c|c|c|c|c|c|c|c|c|c|c|}
\hline & KRTSR & IM & KRIT & UT & IT & CT & GR & SF & $\mathrm{AE}$ & $\mathrm{AU}$ & TU \\
\hline KRTSR & 1 & 0,693 & 0,620 & 0,807 & 0,819 & 0,751 & 0,523 & 0,350 & 0,623 & 0,654 & 0,643 \\
\hline IM & & 1 & 0,813 & 0,423 & 0,505 & 0,716 & 0,704 & 0,720 & 0,860 & 0,808 & 0,872 \\
\hline KRIT & & & 1 & 0,435 & 0,452 & 0,584 & 0,519 & 0,496 & 0,758 & 0,693 & 0,770 \\
\hline UT & & & & 1 & 0,551 & 0,365 & 0,333 & 0,104 & 0,445 & 0,454 & 0,428 \\
\hline IT & & & & & 1 & 0,410 & 0,455 & 0,219 & 0,405 & 0,515 & 0,466 \\
\hline CT & & & & & & 1 & 0,456 & 0,506 & 0,627 & 0,614 & 0,631 \\
\hline GR & & & & & & & 1 & 0,357 & 0,510 & 0,494 & 0,544 \\
\hline SF & & & & & & & & 1 & 0,457 & 0,400 & 0,495 \\
\hline \multirow[t]{2}{*}{$\mathrm{AE}$} & & & & & & & & & 1 & 0,697 & 0,770 \\
\hline & KRTSR & IM & KRIT & UT & IT & CT & GR & SF & $\mathrm{AE}$ & $\mathrm{AU}$ & TU \\
\hline AU & & & & & & & & & & 1 & 0,663 \\
\hline TU & & & & & & & & & & & 1 \\
\hline
\end{tabular}

KRTSR:Kurumsal Tasarım, KGK:Kurumsal Görsel Kimlik, IM:Kurumsal İmaj, KRIT:Kurumsal İtibar, UT:Ürün Tasarımı, IT:İletişim Tasarımı, CT:Çevre Tasarımı, GR:Görünebilirlik, SF:Şeffaflık, AE:Ayırt Edilebilirlik, AU:Aslına Uygunluk, TU: Tutarlılık.

Araştırmanın bağımsız değişkenleri olan "kurumsal tasarım" ve "kurumsal imaj" ile bağımlı değişkeni olan "kurumsal itibar" ile olan ilişkisi incelendiğinde, kurumsal tasarım ile kurumsal itibar arasında orta düzeyde, kurumsal tasarım ile kurumsal imaj arasında güçlü düzeyde ve kurumsal imaj ile kurumsal itibar arasında yine güçlü düzeyde bir ilişki olduğu görülmüştür. 


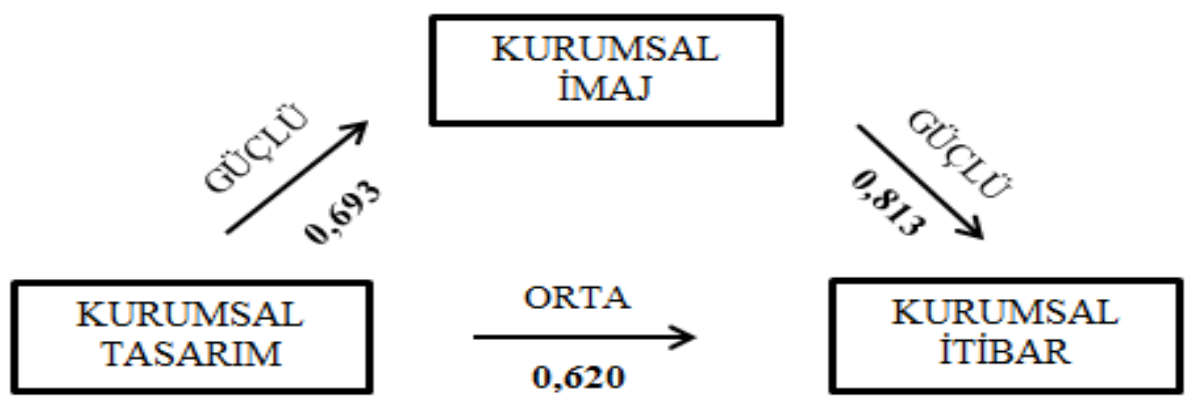

Şekil 5.2. Bağımsız ve Bağımlı Değişkenlerin İlişki Düzeyleri

\section{8. Doğrulayıcı Faktör Analizi}

Oluşturulan modelin, örneklem ve örneklemden elde edilen veri ile uyumlu olup olmadığının analiz edilmesi için AMOS 22.0 paket programı kullanılarak “Doğrulayıcı Faktör Analizi” yapılmıştır.

Tablo 5.4. Kurumsal Tasarım, İtibar ve İmaj İçin Doğrulayıcı Faktör Analizi İstatistikleri

\begin{tabular}{|c|c|c|c|c|c|c|}
\hline \multicolumn{2}{|c|}{ Parametre } & NFI & CFI & IFI & RMSEA & GFI \\
\hline \multicolumn{2}{|c|}{ Kurumsal Tasarım } & 0,91 & 0,90 & 0,93 & 0,070 & 0,90 \\
\hline \multicolumn{2}{|c|}{ Kurumsal İtibar } & 0,92 & 0,94 & 0,95 & 0,063 & 0,91 \\
\hline \multicolumn{2}{|c|}{ Kurumsal İmaj } & 0,94 & 0,96 & 0,96 & 0,077 & 0,94 \\
\hline \multirow{2}{*}{ Uyum Standard1 } & Uyum & $0-0,89$ & $0-0,89$ & $0-0,89$ & $0,05-0,08$ & $0,85-0,89$ \\
\hline & İyi Uyum & $0,90-1$ & $0,90-1$ & $0,9-1$ & $<0,05$ & $>0,90$ \\
\hline
\end{tabular}

Kurumsal Tasarım, İtibar ve İmaj İçin Doğrulayıcı Faktör Analizi İstatistikleri incelendiğinde, NFI, CFI, IFI ve GFI istatistiklerinin 0,90 eşik değerini sağladıkları, RMSEA istatistiklerinin de kabul edilebilir sınırlar olan 0,05 $-0,08$ arasında olduğu görülmektedir.

Tablo 5.5. Kurumsal Tasarım ve Kurumsal İtibar Oluşumu Arasındaki Doğrudan İlişki Durumu standardize edilmiş parametre değerleri $(\beta)$, standart hata, $t$ ve $p$ değerleri.

\begin{tabular}{|c|c|c|c|c|c|}
\hline $\begin{array}{l}\text { Bağımsız } \\
\text { Değişken }\end{array}$ & $\begin{array}{c}\text { Bağımlı } \\
\text { Değişken }\end{array}$ & $\beta$ & Standart Hata & $\mathbf{p}$ & Etki \\
\hline Ürün Tasarımı & \multirow{3}{*}{ Görünebilirlik } & $-0,095$ & 0,073 & 0,190 & Anlamsız \\
\hline İletişim Tasarımı & & 0,263 & 0,020 & 0,000 & Anlamli \\
\hline Çevre Tasarımı & & 0,271 & 0,036 & 0,000 & Anlamli \\
\hline Ürün Tasarımı & \multirow{3}{*}{ Şeffaflık } & $-0,218$ & 0,075 & 0,004 & Anlaml1 \\
\hline İletişim Tasarımı & & 0,074 & 0,059 & 0,208 & Anlamsız \\
\hline Çevre Tasarımı & & 0,538 & 0,071 & 0,000 & Anlamli \\
\hline Ürün Tasarımı & \multirow{3}{*}{ Ayırt Edilebilirlik } & 0,241 & 0,080 & 0,003 & Anlamli \\
\hline İletişim Tasarımı & & $-0,016$ & 0,085 & 0,851 & Anlamsız \\
\hline Çevre Tasarımı & & 0,496 & 0,081 & 0,000 & Anlamlı \\
\hline Ürün Tasarımı & \multirow{3}{*}{ Tutarlılık } & 0,103 & 0,065 & 0,111 & Anlamsız \\
\hline İletişim Tasarımı & & 0,216 & 0,078 & 0,006 & Anlamli \\
\hline Çevre Tasarımı & & 0,516 & 0,056 & 0,000 & Anlamli \\
\hline
\end{tabular}




\subsection{Yapısal Eşitlik Modelinin Test Edilmesi ve Bulgular}

Hipotezlerin test edilmesi, yapısal eşitlik analizi ile gerçekleştirilmiştir. Analiz, doğrudan ( $\left.\mathbf{H}_{1}-\mathbf{H}_{11}\right)$ ve dolaylı etkilerin $\left(\mathbf{H}_{12}-\mathbf{H}_{16}\right)$ analiz edilmesi olmak üzere 2 ana bölümden oluşmaktadır. Doğrudan etkilerin analiz edildiği bölümde, kurumsal tasarımın alt bileşenleri (ürün tasarımı, iletişim tasarımı, çevre tasarımı) bağımsız değişkenler olarak ele alınırken, kurumsal itibar oluşumunun alt bileşenleri (görünebilirlik, şeffaflık, ayırt edilebilirlik, tutarlılık) bağımlı değişken olarak değerlendirilmiştir. Ayrıca, kurumsal imaj, kurumsal tasarım ile analiz edildiğinde bağımlı, kurumsal itibar oluşumu ile analiz edildiğinde bağımsız değişken olarak incelenmiştir.

Yukarıda verilmiş olan araştırma modelinin uyum iyiliği değerleri kontrol edilmiş, daha önceden de belirtildiği gibi ilk aşamada, "aslına uygunluk" alt unsuru modelden çıkarılmış ve analiz yenilenmiştir.

Tablo 5.6. Yapısal Eşitlik Modeli Analiz Sonuçları.

\begin{tabular}{|c|c|c|c|c|c|c|}
\hline \multicolumn{2}{|c|}{ Parametre } & NFI & CFI & IFI & RMSEA & GFI \\
\hline \multicolumn{2}{|c|}{ Sonuç } & 0,83 & 0,89 & 0,88 & 0,061 & 0,79 \\
\hline \multirow{2}{*}{ Uyum Standard1 } & Uyum & $0-0,89$ & $0-0,89$ & $0-0,89$ & $0,05-0,08$ & $0,85-0,89$ \\
\cline { 2 - 7 } & İyi Uyum & $0,90-1,00$ & $0,90-1,00$ & $0,90-1,00$ & $<0,05$ & $>0,90$ \\
\hline
\end{tabular}

Analizin, “aslına uygunluk" alt unsurunun modelden çıkarılarak tekrarlanması sonucunda, uyum istatistiklerinin, minimum değerleri sağladığı görülmüştür.

Tablo 5.7. Yapısal Eşitlik Modeli Düzeltilmiş Analiz Sonuçları.

\begin{tabular}{|c|c|c|c|c|c|c|}
\hline \multicolumn{2}{|c|}{ Parametre } & NFI & CFI & IFI & RMSEA & GFI \\
\hline \multicolumn{2}{|c|}{ Sonuç } & 0,84 & 0,90 & 0,90 & 0,065 & 0,80 \\
\hline \multirow{2}{*}{ Uyum Standard1 } & Uyum & $0-0,89$ & $0-0,89$ & $0-0,89$ & $0,05-0,08$ & $0,85-0,89$ \\
\cline { 2 - 6 } & İyi Uyum & $0,90-1$ & $0,90-1$ & $0,90-1$ & $<0,05$ & $>0,90$ \\
\hline
\end{tabular}

Aslına uygunluk alt bileşeninin doğrulanamamasının nedeninin, sürekli gelişmekte ve en son teknolojiyi uygulamakta olan havacılık sektöründe aslına uygunluğun itibar oluşumunun bir alt unsuru olarak algılanmadığı olduğu değerlendirilmektedir. Havacılık sektörü dışında farklı bir sektörde faaliyet gösteren bir firma üzerinde benzer bir çalışma yapılması durumunda aslına uygunluk faktörünün de diğer faktörler üzerindeki etkisini gözlemlemenin mümkün olabileceği değerlendirilmektedir.

Tablo 5.8. Yapısal Eşitlik Modeli Katsayıları

\begin{tabular}{|c|c|c|c|c|c|}
\hline Bağımsız Değişken & Bağımlı Değişken & B & Standart Hata & $\mathbf{P}$ & Etki \\
\hline Ürün Tasarımı & İmaj & 0,251 & 0,068 & 0,000 & Var \\
\hline İletişim Tasarımı & İmaj & 0,327 & 0,070 & 0,000 & Var \\
\hline Çevre Tasarımı & İmaj & 0,326 & 0,054 & 0,000 & Var \\
\hline \multirow{4}{*}{ Ürün Tasarımı } & Görünebilirlik & $-0,220$ & 0,069 & 0,002 & Var \\
\hline & Şeffaflık & $-0,381$ & 0,096 & 0,000 & Var \\
\hline & Ayırt Edilebilirlik & 0,111 & 0,113 & 0,324 & Yok \\
\hline & Tutarlılık & $-0,061$ & 0,065 & 0,321 & Yok \\
\hline \multirow{3}{*}{ İletişim Tasarımı } & Görünebilirlik & 0,259 & 0,069 & 0,000 & Var \\
\hline & Șeffaflık & $-0,029$ & 0,091 & 0,746 & Yok \\
\hline & Ayırt Edilebilirlik & $-0,316$ & 0,109 & 0,004 & Var \\
\hline
\end{tabular}


F. Canitez - A. Akyol 11/3 (2019) 1294-1312

\begin{tabular}{|l|l|c|c|c|c|}
\hline & Tutarlılık & $-0,011$ & 0,069 & $\mathbf{0 , 8 6 8}$ & Yok \\
\hline \multirow{4}{*}{ Çevre Tasarımı } & Görünebilirlik & 0,329 & 0,061 & 0,000 & Var \\
\cline { 2 - 6 } & Şeffaflık & 0,618 & 0,053 & 0,000 & Var \\
\cline { 2 - 6 } & Ayırt Edilebilirlik & 0,505 & 0,112 & 0,000 & Var \\
\cline { 2 - 6 } & Tutarlılık & 0,339 & 0,059 & 0,000 & Var \\
\hline İmaj & Görünebilirlik & 0,496 & 0,038 & 0,000 & Var \\
\hline İmaj & Şeffaflık & 0,415 & 0,066 & 0,000 & Var \\
\hline İmaj & Ayırt Edilebilirlik & 0,897 & 0,044 & 0,000 & Var \\
\hline İmaj & Tutarlı1 & 0,750 & 0,028 & 0,000 & Var \\
\hline
\end{tabular}

Verilerin analiz edilip yorumlanmasına, hipotezlerdeki sıra takip edilerek başlanmış ve ilk olarak kurumsal tasarım alt unsurlarının, kurumsal imaj üzerindeki doğrudan etkileri incelenmiştir. Buna göre, kurumsal tasarımın alt unsurları olan ürün tasarımı $(p=0,000<0,05)$, iletişim tasarımı $(p=0,000<0,05)$ ve çevre tasarımı da $(\mathrm{p}=0,000<0,05)$ kurumsal imaj üzerinde doğrudan etkisinin bulunduğu görülmüştür. Bu durumda, $\mathbf{H}_{1}$ hipotezi kabul edilmiştir.

Kurumsal tasarımın alt bileşenlerinin, kurumsal itibar oluşumu alt bileşenleri üzerine olan etkisinin anlamlı olup olmadığ 0,05 anlamlılık düzeyinde incelenmiştir. Buna göre, analiz edilen verilerin sonucunda, ürün tasarımının, görünebilirlik ve şeffaflık üzerinde etkisi olduğu $(\mathrm{p}=0,000<0,05)$, diğer alt bileşenler olan ayırt edilebilirlik $(\mathrm{p}=0,324>0,05)$ ve tutarlılık $(\mathrm{p}=0,321>0,05)$ üzerinde bir etkisi olmadığı görülmüştür. İletişim tasarımının, ayırt edilebilirlik ( $\mathrm{p}=0,004<0,05)$ ve görünebilirlik $(\mathrm{p}=0,000<0,05)$ üzerinde etkili olduğu, diğer alt unsurlar olan tutarlılık $(\mathrm{p}=0,868>0,05)$ ve şeffaflık $(\mathrm{p}=0,746>0,05)$ üzerinde herhangi bir etkisinin bulunmadığ 1 görülmüştür. Son alt değişken olan çevre tasarımının ise görünebilirlik, şeffaflık, ayırt edilebilirlik ve tutarlılık (her bir alt unsur için $\mathrm{p}=0,000<0,05$ olmak üzere) alt bileşenlerinin tamamı üzerinde etkili olduğu sonucu elde edilmiştir. Bu sonuçlar göz önünde bulundurulduğunda, $\mathbf{H}_{2}$ (Kurumsal tasarım bileşenlerinin görünebilirlik üzerine etkisi) hipotezi kabul edilmiş, $\mathbf{H}_{3}, \mathbf{H}_{4}$, ve $\mathbf{H}_{6}$ hipotezleri kısmen kabul edilmiştir. Faktör analizi ve araştırma modelinin uyum iyiliği değerleri sonucunda uygunluğu bozduğu düşünülen, $\mathbf{H}_{5}$ hipotezi kabul edilmemiştir.

Doğrudan etkilerin incelendiği son bölümde, kurumsal imajın, kurumsal itibar oluşumu alt unsurları üzerinde etkisinin olup olmadığı incelenmiştir. Yapılan analiz sonucunda kurumsal imajın; görünebilirlik $(\mathrm{p}=0,000<0,05)$, şeffaflık $(\mathrm{p}=0,000<0,05)$, ayırt edilebilirlik $(\mathrm{p}=0,000<0,05)$ ve tutarlılık $(\mathrm{p}=0,000<0,05)$ alt bileşenlerinin tamamı üzerinde etkili olduğu sonucu elde edilmiştir. Buna göre, $\mathbf{H}_{7}, \mathbf{H}_{8}, \mathbf{H}_{9}$, ve $\mathbf{H}_{11}$ kabul edilmiştir. Faktör analizi ve araştırma modelinin uyum iyiliği değerleri sonucunda uygunluğu bozduğu düşünülen, $\mathbf{H}_{10}$ hipotezi kabul edilmemiştir.

\section{SONUÇLAR VE ÖNERİLER}

Benzer mal ve hizmet sunulan bir ortamda sürdürülebilir büyüme ve başarı elde etmek, ancak müşterinin nezdinde rakiplerden farklı algılanma ile mümkündür. Bir kurumun tasarımı, imajı ve itibarı bu farklılaşmayı sağlayan ana etkenlerin başında gelmektedir.

Yapılan araştırmalarda, tüketicilerin herhangi bir satın alma gerçekleştirdiklerinde, sadece satın aldıkları ürünün kendilerine sağladığı faydaya odaklanmadıkları, aynı zamanda ürününü satın aldıkları kurumun kurumsal tasarımına, imajına ve itibarına da önem verdikleri ortaya çıkmıştır (Uzunoğlu ve Öksüz, 2008). Özellikle fiyat, kalite, fayda, satış sonrası servis, garanti gibi hususlar birbirine yakın olduğunda kurum itibarının tüketici tercihine etkisi büyük ölçüde olmaktadır. Bazen kaliteli ürünlerin uygun fiyatlarında dahi alıcı bulamadıkları görülmektedir. Bunun nedenlerinden biri firma hakkındaki olumsuz imaj ve itibardır.

Kar amacı güden kurumların, karlılık ve büyüme hedeflerinin, farklılaşma, dolayısıyla iyi bir kurumsal tasarım, kurumsal imaj ve kurumsal itibar oluşturmaktan geçmesi nedeniyle, kurumsal itibar oluşumunu etkileyen değişkenler ve kurumsal itibar oluşumu bileşenleri iyi analiz edilmelidir. Bu nedenle bu çalışmada, 
kurumsal tasarımın alt unsurlarının, kurumsal itibar oluşumu üzerindeki varsayılan doğrudan etkisinin ve kurumsal imaj üzerinden dolaylı etkisinin istatistiksel olarak anlamlı olup olmadığı araştırılmıştır.

Karlılık ve büyüme hedeflerinin, iyi bir kurumsal imaj çizmekten geçer. Bu bilgiden yola çıkarak piyasada kalıcı olmayı hedefleyen ticari bir kurumun, kurumsal imajını mümkün olduğunca olumlu seviyede tutarak, piyasada itibar kazanmayı amaçlaması doğal bir durumdur. Bu nedenle, çalışmanın alt başlıklarından biri olan kurumsal imajın, kurumsal itibar oluşumu üzerine doğrudan etkili olması da beklenen bir sonuçtur. Kurumsal imajın, kurumsal itibar oluşumu ve bileşenleri ile olan korelasyonuna bakıldığında, yüksek bir ilişki $(\mathrm{r}=0,813)$ olduğu da görülmüştür. Bu korelasyonun, istatistiksel olarak da anlamlı olup olmadığını tespit etmek için yapılan doğrusal regresyon analizi sonucunda, kurumsal imajın, kurumsal itibar oluşumunun her bir alt unsuru üzerinde doğrudan etkisinin anlamlı olduğu $(p=0,000<0,05)$ sonucuna ulaşılmıştır. Bu nedenle uzun vadeli düşünen bir firmanın, yukarıda kısa vadeli hedeflerini sağlaması için bir ön koşul olarak belirtilen olumlu "kurumsal imaj" oluşturma gerekliliği, anlamlı çıkan bu ilişkiyle bir kez daha gösterilmiştir.

Araştırmanın en önemli çıktısı kurumsal tasarımın kurumsal itibar oluşumunu etkilediğinin istatistiksel olarak anlamlı çıkmasıdır. Aynı sonuç Alessandri vd., (2006), Mohamad vd., (2007), Money vd., (2010), Meijer ve Kleinnijenhuis, (2006) çalışmalarında da ortaya çıkmıştır.

Bir diğer sonuç kurumsal tasarımın kurumsal imajı etkilediğinin ortaya çıarılmasıdır. Söz konusu sonuç Foroudi, vd., (2014), Jun, vd., (2008), Regina and Daubaraite, (2011), Sharifah and Kitchen, (2014) çalışmaları ile paralellik göstermektedir.

Araştırmanın bir diğer önemli sonucu da kurumsal imajın kurumsal itibar oluşumunu etkilediğinin istatistiksel olarak doğrulanmış olmasıdır. Aynı sonuç Foroudi, vd., (2014) ve Park, Lee, Kim, (2014) çalışmalarında da ortaya çıkmıştır. Ayrıca literatürde de kurumsal imajın kurumsal itibar oluşumunu etkilediği kabul edilmiştir.

Diğer bir açıdan incelendiğinde araştırma sonuçları; kurumsal tasarım, kurumsal imaj ve kurumsal itibar oluşumu bileşenlerinin ne kadar önemli olduğunu göstermekte, yöneticilerin her bileşen üzerinde iyileştirme projeleri geliştirmesini ve buna benzer projeleri desteklemesini önermektedir. Kurumsal tasarım, kurumsal imaj ve kurumsal itibar oluşumunun birbiri ile olan çok yönlü ilişkisi düşünüldügünde yöneticilerin firmaları ile ilgili pazarlama faaliyetlerinde bu üç alanı bir bütün olarak ele alıp daha kapsayıcı ve bütünleşik bir strateji benimsemelerinin firmanın stratejik hedeflerini gerçekleştirmesine katkı sağlayacağı düşünülmektedir.

Olumlu imajın devamlılığının sağlanması, uzun vadede iyi bir itibarın kazanılmasını sağlayacaktır. Ayrıca kurumsal tasarımın da imaj üzerindeki etkisi olduğu bu çalışmada görülmüştür. Bu nedenlerle yöneticilerin olumlu kurumsal itibar oluşturmalarının şart olduğu, bunu da firmalarının kurumsal tasarımına gerekli önemi vermeleri ve kurumsal imajı uzun vadede üst seviyede tutarak sağlayabilecekleri değerlendirilmektedir.

\section{Sektör Uygulayıcılarına Öneriler}

Kurumsal itibarın kurumun uzun vadeli politika ve uygulamaları sonucu oluşturulabilmesi nedeniyle yöneticiler; kurumsal itibarı yükseltecek bir plan hazırlamalı, elde edilen sonuçları değerlendirerek geri besleme ile planı revize etmeli ve uzun dönemde uygulamalıdır.

Yöneticilerin piyasada kalma, sürdürülebilir rekabet üstünlüğü sağlama ve dolayısıyla ortalamanın üzerinde kar elde etmek maksadıyla, ısrarla ve önemle üzerinde durmaları ve kendilerine sormaları gereken soru; "müşterilerin veya tüketicilerin nezdinde nasıl özel bir konuma sahip olmalıyım, nasıl olumlu anlamda farklı algılanmalıyım" olmalıdır. Daha önce de değinildiği gibi kurumsal itibar paydaşların kurum hakkındaki değerlendirmeleridir. Bu nedenle bu sorunun da cevabı iyi bir kurumsal itibar kazanılmasından başka bir şey değildir. Çünkü iyi bir kurumsal itibar (Karaköse, 2007:4); rakiplerin engelleme faaliyetlerine karşı bariyer görevi görür ve rekabet avantajı sağlar. En yetenekli elemanları çeker, örgütsel süreçteki eksikliklerin giderilmesine yardımcı olur. En iyi tedarikçileri ve iş ortaklarını çeker. Yatırımcılardan ve zengin ekonomik kaynaklardan faydalanma şansını artıır. Yeni pazarların kapılarını açar. Örgütün mal ve hizmetleri için bir değer yaratır. Kriz zamanlarında örgütü korur. Yöneticiler özellikle kriz dönemlerinde itibarın kurumlarını koruyacağı düşüncesinden hareketle, paydaşların firma hakkındaki itibar algısını olumsuz yönde etkileyecek davranışlardan kaçınmalıdır. 
F. Canitez - A. Akyol 11/3 (2019) 1294-1312

İtibarın genel olarak paydaşların kurum hakkındaki genel algısı olduğu gerçeğinden hareketle yöneticiler; paydaş grupların firmayı nasıl algıladıklarını tespit etmeli ve bu algıyı olumlu yönde etkilemek için neler yapılabileceğini ortaya çıkarmalı ve buna uygun projeler geliştirmelidir.

Kurumsal tasarım, kurumsal imaj ve kurumsal itibarın oluşturulabilmesi için gerekli bileşenlerini ortaya çıkarmak yöneticiler için hayati öneme haizdir. Yöneticiler bu bileşenleri kullanarak kurumlarını stratejik hedeflerine ulaştıracak hareket tarzlarını ortaya koymalıdırlar.

Uzun vadeli olarak ortalamanın üzerinde gelir elde etmeyi hedef alan kurum yöneticileri, çalıştıkları kurumlarla iyi iletişim içinde olmak, gerek marka yönetimi gerek çevre tasarımına gereken önemi vermek, bu sayede iyi bir imaj ve uzun vadede olumlu bir itibar elde etmek ve bunu korumak zorundadırlar. Uzun süreli ve güvenilir bir ilişki kuramayan yöneticilerin olumlu bir itibar kazanamadıkları ve sürekliliklerini sağlama konusunda zorluklar yaşadıkları gözlemlenmiştir (Saylı vd., 2009:172).

Çalışmada itibarı oluşumu bileşenleri (görünebilirlik, şeffaflık, ayırt edilebilirlik, aslına uygunluk, tutarlılık) ve itibar oluşumunu etkileyen değişkenler (kurumsal tasarım ve imaj) ortaya konmuş, yapılan saha çalışması ile kurumsal tasarımın (direk ve dolaylı) ve imajın itibar oluşumuna olan etkisi istatistiksel olarak doğrulanmıştır.

\section{KAYNAKÇA}

Akahmet, D. (2006). Kurumsal İtibar Yönetimi ve Bir Uygulama. Marmara Üniversitesi Sosyal Bilimler Enstitüsü Uluslararası Kalite Yönetimi Bilim Dalı Yüksek Lisans Tezi. İstanbul.

Alessandri, S., W., Yang, S. Kinsey D.F. (2006), “An Integrative Approach to University Visual Identity and Reputation", Corporate Reputation. Corporate Reputation Review.

Anca, C. E., ve Roderick, B. (2007). The Influence of Brand Image and Company Reputation Where Manufacturers Market to Small Firms: A Customer Value Perspective. Industrial Marketing Journal, 36, 135-137.

Balmer, J.M.T. (1995), “Corporate Branding and Connoisseurship', Journal of General Management,

Bartholme, R. H., ve Melewar, T. (2011). Remodelling the Corporate Visual Identity Construct. Corporate Communications: An International Journal, 16(1), 53-64.

Bayar, Y., (2018), Kurumsal İtibar Algısının Örgütsel Vatandaşlık Davranışına Etkisi: İYTE Öğrencilerine Yönelik Araştırma, Adnan Menderes Üniversitesi, Sosyal Bilimler Üniversitesi, Yüksek Lisans Tezi

Birkigt, K., Stadler, M. H., ve Funck, H. J. (1993). Corporate Identity: Grundagen, Funktionen, Fallbeispiele (Cilt 6). Landsberg/Lech: Verlag Modeme Industrie.

Bosch, V.D., Annette L.M., Menno D.T.J, Elving,W.J.L. (2005). How Corporate Visual Identity Supports Reputation. Corporate Communications: An International Journal, 10(2).

Bozkurt, G. (2005). Türk Kimliği Kültür Tarihinin Kaynakları. İstanbul: Remzi Kitabevi.

Dentchev, N., ve Aimé, H. (2006, Aralık 16). Reputation Management: Sending the Right Signal to the Right Stakeholder.

Dowling, G. (1994). Corporate Reputation - Strategies for Developing The Corporate Brand. London: Kogan Page.

Duncan, T. (2002). Integrated Marketing Communications Using Advertising ve Promotion to Build Brands. Boston: Mcgraw-Hill Irwin.

Dumlu, H. ve Kaygısız, E.G., (2018), Kurumsal İtibar Bağlamında Türk Futbol Takımlarının Web Sitelerinin Değerlendirilmesi: Süper Lig Örneği, Üçüncü Sektör Sosyal Ekonomi Dergisi, 53 (3), 1258-1272

Erdem, N., (2015), Kurumsal Kimlik Çalışmalarının Görsel Etkisi, İstanbul Arel Üniversitesi, Sosyal Bilimler Enstitüsü, Yüksek Lisans Tezi

Erdoğan, Z., ve Gönüllüoğlu, S. (2006). Kurumsal İmaj Oluşturulmasına İlişkin Bir Literatür Taraması. Pazarlama Dünyası Dergisi(5), 46-53.

Fombrun, C., ve Riel, C. V. (1997). The Reputational Landscape. Corporate Reputation Review, 1(1), 5-13. 
F. Canitez - A. Akyol 11/3 (2019) 1294-1312

Fombrun, C., ve Riel, C. V. (2004). Fame and Fortune. How Successful Companies Build Winning Reputations. New Jersey: Prentice Hall.

Foroudi, P., Melewar, T.C., Gupta, S. (2014). Linking corporate logo, corporate image, and reputation: An examination of consumer perceptions in the financial setting. Journal of Business Research

Gülsoy, T. (1998). Reklam Terimleri ve Kavramları Sözlüğ̈̈. İstanbul: Adam Yayınları.

Gümüş, M., ve Öksüz, B.; (2009). 'Çalışanların Kurumsal İtibar Sürecine Katılımlarında İçsel İletişimin Rolü', Journal of Yasar University,

Gürses, S., ve Kılıç, K. C. (2013). Corporate Image Aspect Of Corporate Management in Healthcare Industry: Definition, Measurement and An Empirical Investigation. International Business Research, 6(12), 31-45.

Jun, J. W., Cho, C.-H., ve Kwon, H. J. (2008). The Role of Affect and Cognition in Consumer Evaluations of Corporate Visual Identity: Perspectives From the United States and Korea. Brand Management, 15(6), 382-398.

Kara, A. İ. (2014). Kurumsal Kültür, Kurumsal Kimlik ve Kurumsal İmajın Kurumsal İtibar Üzerine Etkileri, Bir İşletme Örneği. Yüksek Lisans Tezi Beykent Üniversitesi Sosyal Bilimler Enstitüsü. İstanbul.

Karaköse, T. (2007), 'Örgütlerde İtibar Yönetimi', Akademik Bakış Uluslararası Hakemli Sosyal Bilimler E-Dergisi,

Kaya, İ. (2006). Bankalarda Kurumsal Kimlik ve Tasarım Anlayışı Üzerine. İstanbul: Marmara Üniversitesi Güzel Sanatlar Enstitüsü İçmimarlık Bölümü Yüksek Lisans Tezi.

Koçer, S., (2017), Kurumsal Web Sitelerinin Kurum Kimliği Açısından İncelenmesi: En Çok Tercih Edilen Üniversiteler Üzerine Bir Analiz, Cilt 10, Sayı 53, 756-772

Kiessling, F. W., ve Spanagli, P. (1996). Corporate Identity Unternehmens Leitbild Organisationskultur. Alling: Sandmann.

Meijer, M.M., Kleinnijenhuis. J., (2006), News and corporate reputation: Empirical findings from the Netherlands, Public Relations Review 32.

Melewar, T. C., ve Jenkins, E. (2002). Defining the Corporate Identity Construct. Corporate Reputation Review, $5(1), 76-91$.

Melewar, T., ve Karaosmanoğlu, E. (2006). Seven Dimensions of Corporate Identity: A Categorisation From The Practitioners' Perspectives. European Journal of Marketing, 40(7/8), 846-869.

Mohamad, B., Bakar, H.A., Abdul, R.N.A.A. (2007). Relationship Between Corporate identity and corporate Reputation: A Case of a Malaysian Higher Education Sector. Jurnal Manajemen Memasaran, Vol. 2, no. 2.

Money, K., Rose, S., Hillenbrand, C., (2010), The impact of the corporate identity mix on corporate reputation, Brand Management Vol. 18, 3.

Nguyen, N., ve Leblanc, G. (2001). Corporate Image and Corporate Reputation in Customers Retention Decision in Services. Journal of Retailing and Consumer Services, 8, 227-238.

Odabaşı, Y., ve Oyman, M. (2002). Pazarlama İletişimi Yönetimi. Eskişehir: Mediacat.

Odabaşı, Y., (1995) Pazarlama İletişimi, Anadolu Üniversitesi Yayınları,

Okay, A. (2000). Kurum Kimliği. Maltepe Üniversitesi İletişim Fakültesi Dergisi(1), 121-134.

Okay, A. (2012). Kurum Kimliği. İstanbul: Derin Yayınları.

Önal, G. (2000). Halkla İlişkiler. İstanbul: Türkmen Kitapevi.

Öztürk, M. C. ve Şardağı, E., (2018), Kurumsal Kimlik Aracı Olarak Facebook: Türkiye'deki Sivil Toplum Kuruluşları (STK) Üzerine Bir Değerlendirme, Galatasaray Üniversitesi İleti-ş-im Dergisi 28, 115-141

Park, J., Lee, H., Kim, C., (2014), Corporate social responsibilities, consumer trust and corporate reputation: South Korean consumers' perspectives, Journal of Business Research 67. 
F. Canitez - A. Akyol 11/3 (2019) 1294-1312

Regenthal, G. (1992). Identiat Und Image-Praxishilfen Für Das Management İn Wirschaft. Köln: Wirstchafttsverl.Bachem: Bildung Und Gesellschaft.

Regina, V. ve Daubaraite, U., (2011), Corporate Social Responsibility in Forming Corporate Image, Inzinerine Ekonomika-Engineering Economics, 2011, 22(5)

Ruyter, K. ve Wetzels, M. (2000) “The Role of Corporate Image and Extension Similarity in Service Brand Extensions". Journal of Economic Psychology.

Salman, G. ve Eroğlu, E., (2017), Sosyal Medyada Kurum Kimliği Yönetimi: Türkiye'nin En Büyük 500 Şirketi Üzerine Bir Araştırma, Gümüşhane Üniversitesi, Illetişim Fakültesi Elektronik Dergisi, Cilt 5, Sayı 1, 525 547

Savaşkan, Ayşe Gül, (2017), Bölgesel Kalkınma Ajanslarının Kurumsal Kimlik Bileşenlerinin İncelenmesine Yönelik Bir Araştırma, Batman Üniversitesi, Sosyal Bilimler Enstitüsü, Yüksek Lisans Tezi

Saylı, H., Ağca, V., Kızıldağ, D., ve Uğurlu, Ö. Y. (2009). Etik, Kurumsal İtibar ve Kurumsal Performans İlişkisini Belirlemeye Yönelik İlk 500 İşletme İçinde Yapılmış Bir Araştırma. Süleyman Demirel Üniversitesi Ktisadi ve İdari Bilimler Fakültesi Dergisi, 14(2), 171-180.

Sharifah, F. S. A., Kitchen. P. J. (2014 ), Projecting Corporate Brand Image and Behavioral Response in Business Schools: Cognitive or Affective Brand Attributes, Journal of Business Research 67.

Theaker, A. (2006). Halkla İlişkilerin El Kitabı. (M. Yoz, Çev.) İstanbul: Mediacat Yayınları.

Topçu, Ö. (2017), Kurumsal Kimlik Oluşturmada Bir Logonun Markaya Etkisi, Yeni Medya Elektronik Dergi, Cilt 1, Sayı 2, 157-163

Turhanoğulları, M. (2010). Kurum Kimliğinin Kurumsal İmaja Etkisi; Antalya Trafik Denetleme Şubesi Üzerine Bir Araştırma. Akdeniz Üniversitesi Sosyal Bilimler Enstitüsü Halkla İlişkiler ve Tanıtım Anabilim Dalı Yüksek Lisans Tezi. Antalya.

Uslu, P. (2006). “Kurumsal Kimlik Oluşturmada Halkla İlişkilerin Önemi Özdilek Örneği”. Yüksek Lisans Tezi. Kocaeli: Kocaeli Üniversitesi.

Usta R., (2012). Kurumsal Kimlikte Kültürün Yansıması. Yüksek Lisans Tezi, Haliç Üniversitesi. İstanbul.

Uzunoğlu, E., ve Öksüz, B. (2008). Kurumsal İtibar Risk Yönetimi: Halkla İlişkilerin Rolü. Selçuk İletişim Dergisi, $5(3)$.

Ülger, B. (2003). İ̧sletmelerde İletişim ve Halkla İlişkiler. İstanbul: Der Yayınları. 